\title{
Volumetric characteristics and compactability of asphalt rubber mixtures with organic warm mix asphalt additives
}

\author{
A.M. Rodríguez-Alloza ${ }^{\mathrm{a}} \bowtie$, J. Gallego ${ }^{\mathrm{b}}$ \\ a. Department of Civil Engineering: Construction, Infrastructure and Transport, Technical University of Madrid (UPM), \\ (Madrid, Spain) \\ b. Department of Civil Engineering: Transport, Technical University of Madrid (UPM), (Madrid, Spain) \\ $\triangle$ anamaria.rodriguez.alloza@upm.es
}

\author{
Received 3 March 2016 \\ Accepted 13 September 2016 \\ Available on line 22 March 2017
}

\begin{abstract}
Warm Mix Asphalt (WMA) refers to technologies that reduce manufacturing and compaction temperatures of asphalt mixtures allowing lower energy consumption and reducing greenhouse gas emissions from asphalt plants. These benefits, combined with the effective reuse of a solid waste product, make asphalt rubber (AR) mixtures with WMA additives an excellent environmentally-friendly material for road construction. The effect of WMA additives on rubberized mixtures has not yet been established in detail and the lower mixing/compaction temperatures of these mixtures may result in insufficient compaction. In this sense, the present study uses a series of laboratory tests to evaluate the volumetric characteristics and compactability of AR mixtures with organic additives when production/compaction temperatures are decreased. The results of this study indicate that the additives selected can decrease the mixing/compaction temperatures without compromising the volumetric characteristics and compactability.
\end{abstract}

KEYWORDS: Rubber; Warm mix asphalt; Organic additive; Volumetric characteristics; Compactability

Citation/Citar como: Rodríguez-Alloza, A.M.; Gallego, J. (2017) Volumetric characteristics and compactability of asphalt rubber mixtures with organic warm mix asphalt additives. Mater. Construcc. 67 [327], e123. http://dx.doi. org/10.3989/mc.2017.03616

RESUMEN: Características volumétricas y compactabilidad de mezclas con caucho y aditivos de mezclas semicalientes orgánicos. Las mezclas semicalientes permiten reducir las temperaturas de fabricación y compactación de las mezclas asfálticas y disminuir el consumo de energía y emisión de gases de efecto invernadero en las plantas asfálticas. Estos beneficios, junto con la reutilización efectiva de un producto de desecho, harían de las mezclas con caucho y aditivos de mezclas semicalientes un excelente material para la construcción de carreteras respetuoso con el medio ambiente. En esta investigación se estudia, a través de una serie de ensayos de laboratorio, las características volumétricas y de compactabilidad de las mezclas con caucho y aditivos orgánicos de mezclas semicalientes, ya que se desconoce el efecto de estos aditivos al disminuir las temperaturas de producción/compactación, pudiendo tener lugar una compactación insuficiente. Los resultados han indicado que los aditivos seleccionados pueden disminuir las temperaturas de producción/compactación de las mezclas sin comprometer las características volumétricas y la compactabilidad.

PALABRAS CLAVE: Caucho; Mezcla semicaliente; Aditivo orgánico; Características volumétricas; Compactabilidad ORCID ID: A. M. Rodríguez-Alloza (http://orcid.org/0000-0001-7063-9801); J. Gallego (http://orcid.org/ 0000-0002-1343-3185)

Copyright: (C) 2017 CSIC. This is an open-access article distributed under the terms of the Creative Commons Attribution License (CC BY) Spain 3.0. 


\section{INTRODUCTION}

Previous studies indicate that asphalt pavements with crumb-rubber modified (CRM) binders improve resistance to rutting, fatigue and thermal cracking, as well as reducing traffic noise, maintenance costs and also contribute to prolonged pavement life (1-7). However, asphalt rubber (AR) mixtures present a major drawback that the manufacturing temperature is higher. Temperatures normally oscillate between $175^{\circ} \mathrm{C}$ and $180^{\circ} \mathrm{C}(8)$ as the rubber lends a greater viscosity to the binder and thus produces larger amounts of greenhouse gases (GHG) compared to conventional bituminous mixtures.

Warm Mix Asphalt (WMA) technology has been developed to reduce the manufacturing and compaction temperatures of asphalt mixtures and thus decrease energy consumption, GHG emissions, fumes and odours from asphalt plants as well as improving working conditions at plants and paving sites $(9,10)$. Therefore, AR mixtures used with WMA additives offer effective reuse of waste and an environmentally friendly road construction material.

The reduction of production/compaction temperatures could lead to inadequate volumetric properties and, in consequence, to an impoverished mechanical performance of the mixtures $(11,12)$. If these mixtures do not perform well, there will be no long-term energy savings or environmental benefits. For this reason, it was considered necessary to perform a preliminary study of the volumetric characteristics and compactability of AR mixtures with WMA additives (referred to hereafter as AR-WMA mixtures) and to determine the permissible reduction of production/compaction temperatures, as this is the main purpose of the WMA technology.

Akkisety et al. (13) studied the influence of temperature on the manufacture of CRM asphalt mixtures with two WMA additives. This study demonstrated that the percentage of voids filled with asphalt increased and that the percentage of voids in the mineral aggregate decreased. The laying temperature was also reduced compared to hot mix asphalt (HMA) while maintaining a suitable void content in the mixture. Other studies have determined production and compaction temperatures using the impact compactor (same as used in the Marshall method), monitoring the thickness of each specimen during the compaction. It was found that the compactability of the WMA mixtures studied was similar or even better than that of the corresponding HMA mixtures $(14,15)$.

However, the volumetric characteristics of WMA mixtures may vary depending on aspects such as the specific WMA technology applied (organic additives, chemical additives or foaming processes), type of mixture studied (dense-graded asphalt, polymer-modified asphalt, stone mastic asphalt, AR mixtures or asphalt incorporating Reclaimed Asphalt Pavement) and testing conditions (temperature and loading characteristics). As a result, the effect of the WMA additives on volumetric characteristics and the permissible practical range for reduction of mixing/compaction temperature has not been established in detail yet and is still under investigation.

In this study, the volumetric characteristics and compactability of AR-WMA mixtures with organic additives were evaluated in order to assess the effect of the additives when production/compaction temperatures are decreased as well as establishing the attainable decrease in production temperatures through a series of laboratory tests.

Furthermore, one of the main contributions of this study is a comparative study of four organic additives. The selection of organic additives and their dosage, was determined on the basis of a previous study (16) where it was found that the WMA additives selected for the present study were able to reduce the viscosity of a $20 \%$ CRM binder $(20 \%$ by weight of rubber added to a 50/70 pen bitumen) and hence, in theory, these additives were effective for reducing the manufacturing temperature of an AR mixture.

\section{MATERIALS AND METHODS}

The following sections describe the materials used throughout the whole investigation.

\subsection{Virgin binder}

The virgin binder used in this study is a 50/70 pen bitumen, which is widely used to produce asphalt mixes at conventional temperatures.

Penetration grade was assessed according to EN 1426 (17), while the softening point was measured according to EN 1427 (18). The asphalt bitumen was also subjected to a fractionation analysis as specified in the NLT 373/94 standard (19).

Table 1 summarises the basic characteristics of the virgin binder.

TABLE 1. Characteristics of 50/70 pen bitumen

\begin{tabular}{lcc}
\hline Properties & Unit & Test results \\
\hline Penetration $\left(25^{\circ} \mathrm{C}\right)$ & $0.1 \mathrm{~mm}$ & 55.4 \\
Softening point & ${ }^{\circ} \mathrm{C}$ & 51.1 \\
Composition & Unit & Test results \\
Asphaltenes & $(\%)$ & 13.8 \\
Saturates & $(\%)$ & 9.7 \\
Naphthene-aromatic & $(\%)$ & 48.5 \\
Aromatic-polar & $(\%)$ & 28.0 \\
\hline
\end{tabular}




\subsection{Crumb rubber modifier}

The crumb rubber modifier was manufactured by mechanical grinding at ambient temperature $(50 \%$ from truck tyres and 50\% from car tyres) and to ensure consistency only one batch of crumb rubber was used in this study. The gradation of the crumb rubber is provided in Table 2 and the thermal gravimetric analysis in Table 3, both provided by the supplier. Twenty percent was selected as the appropriate amount of crumb rubber with respect to viscosity and workability (20), reflective cracking (21) and cost efficiency (22).

\subsection{WMA additives}

The WMA additives selected for this study consisted of four different organic or wax additives. A $4 \%$ of each additive, referring to the modified bitumen weight, was added to the $20 \%$ CRM binder to produce the CRM binders with WMA additives.

The first additive used in this study (A1) is a Fischer-Tropsch (F-T) wax, produced by treating hot coal with steam in the presence of a catalyst. It is a long-chain aliphatic hydrocarbon wax with the melting range between $85^{\circ} \mathrm{C}$ and $115^{\circ} \mathrm{C}$. The second additive (A2) is a Montan wax, which is produced by solvent extraction of lignite or brown

TABLE 2. Thermal gravimetric analysis of crumb rubber and gradation of crumb rubber

\begin{tabular}{lc}
\hline TGA & Rubber \\
\hline Plasticizer + additives (\%) & 4.67 \\
Polymer (rubber) (\%) & 57.41 \\
Carbon black (\%) & 32.22 \\
Ash (\%) & 6.02 \\
Sieve (mm) & Accumulated (\%) \\
2.0 & 100.0 \\
1.5 & 100.0 \\
1.0 & 100.0 \\
0.50 & 94.1 \\
0.250 & 23.7 \\
0.125 & 3.7 \\
0.063 & 0.4 \\
\hline
\end{tabular}

TABLE 3. Aggregates

\begin{tabular}{lcc}
\hline Aggregate & Size (mm) & $\%$ \\
\hline Mylonite & $8 / 11$ & 20 \\
Mylonite & $4 / 8$ & 48 \\
Limestone & $2 / 4$ & 18 \\
Limestone & $0 / 2$ & 13 \\
Calcareous filler & & 1 \\
\hline
\end{tabular}

coal and that melts at $125^{\circ} \mathrm{C}$. The third organic additive (A3) is a refined Montan wax blended with a fatty acid amide and its melting point lies between $82^{\circ} \mathrm{C}$ and $95^{\circ} \mathrm{C}$. The fourth wax (A4) is a synthetic fatty acid amide that is manufactured by reacting amines with fatty acids which melts between $141^{\circ} \mathrm{C}$ and $146^{\circ} \mathrm{C}$.

\subsection{Aggregates}

The aggregates used to produce the asphalt mixtures were mylonite (a metamorphic rock), limestone and the calcareous filler. The different fractions are reported in Table 3. To ensure consistency, the same aggregates were used throughout this study. The grading curve can be observed in Figure 1.

\subsection{Preparation of CRM binders containing WMA additives}

Twenty percent by weight of rubber was added to the $50 / 70$ virgin binder in order to obtain the $20 \%$ CRM binder used in this study. An oil bath with a maximum temperature of $225^{\circ} \mathrm{C}$, a mixer with a maximum velocity of $15,000 \mathrm{rpm}$, fitted with a propeller agitator and a one-litre metal container for mixing were used for the preparation of the binders. The oil bath was fitted with a temperature probe that could be introduced into the mixing receptacle, allowing the temperature of the binder to be controlled with a precision of $\pm 1{ }^{\circ} \mathrm{C}$. A bitumen sample of $750 \mathrm{~g}$ was heated at $140{ }^{\circ} \mathrm{C}$ and then placed in the oil bath. WMA additives were carefully introduced with the bitumen and the blends were subsequently mixed for $15 \mathrm{~min}$ utes at 4,000 rpm, ensuring that the additive was properly incorporated into the binder. The blend was then heated to $185^{\circ} \mathrm{C}$ and the crumb rubber was added. The mixture was blended for $30 \mathrm{~min}-$ utes at 2,000 rpm and then for another 30 minutes at $900 \mathrm{rpm}$ at a constant temperature of $185^{\circ} \mathrm{C}$. Reheating and homogenization were carefully carried out at a controlled temperature in order to obtain reproducible results (23). Special attention was then paid to the thermal history and storage conditions of the test samples $\left(1 \mathrm{~h}\right.$ at $\left.25^{\circ} \mathrm{C} \pm 0.5^{\circ} \mathrm{C}\right)$ before testing, taking into account their influence on rheological measurements (24).

\subsection{Mixtures studied}

In the present study, thirteen bituminous mixtures were examined. The control mixture was an AR mixture containing $9 \%$ of modified binder referred to the total weight of the dry aggregates. The modified binder was a $20 \%$ CRM binder $(80 \%$ bitumen, $20 \%$ rubber).

The other twelve mixtures were AR-WMA mixtures, also with $9 \%$ of binder, which contained $20 \%$ 


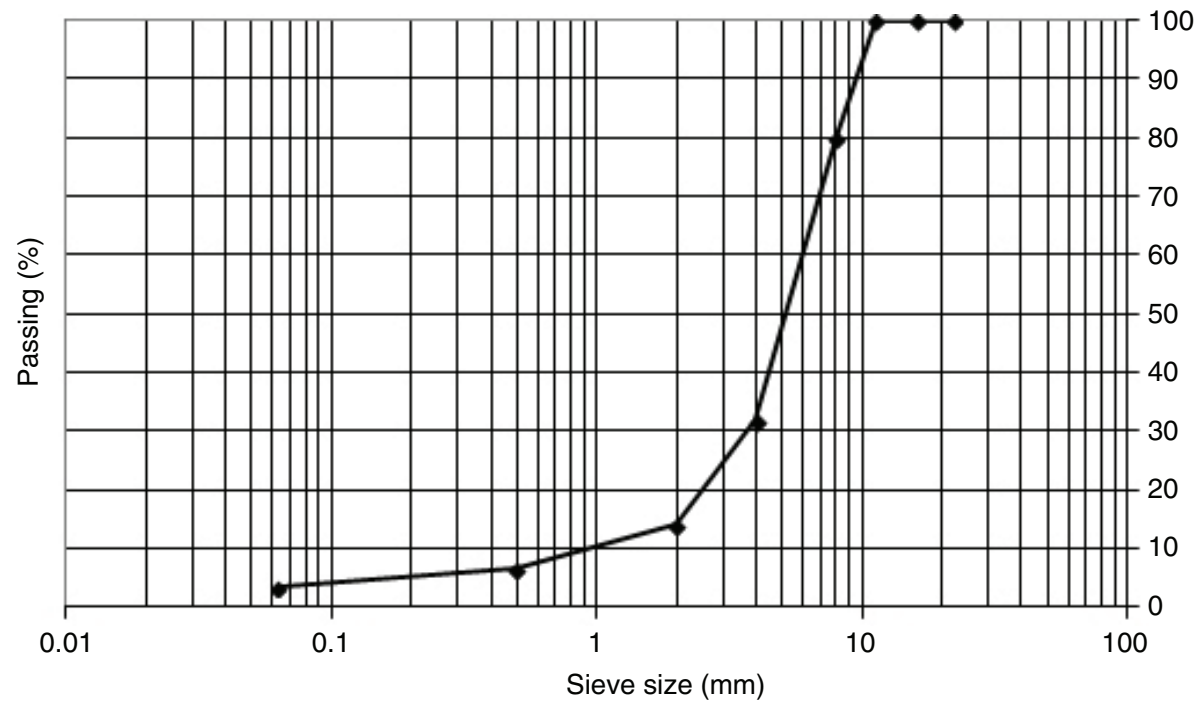

FIGURE 1. Grading curve of the AR mixture.

TABLE 4. Asphalt rubber mixtures studied

\begin{tabular}{llccccc}
\hline Mixture name & Type of mixture & Rubber $(\%)$ & Additive $(\%)$ & WMA additive & Production T $\left.\mathbf{~}^{\mathbf{}}{ }^{\circ} \mathbf{C}\right)$ & Compaction T $\left({ }^{\circ} \mathbf{C}\right)$ \\
\hline AR & Control & 20 & 0 & - & 180 & 170 \\
AR+A1 & AR-WMA & 20 & 4 & A1 & $170,160,150$ & $160,150,140$ \\
AR+A2 & AR-WMA & 20 & 4 & A2 & $170,160,150$ & $160,150,140$ \\
AR+A3 & AR-WMA & 20 & 4 & A3 & $170,160,150$ & $160,150,140$ \\
AR+A4 & AR-WMA & 20 & 4 & A4 & $170,160,150$ & $160,150,140$ \\
\hline
\end{tabular}

of CRM and $4 \%$ of the additive by the weight of modified binder. The asphalt mixtures selected for this study are listed in Table 4 where the contents of rubber and additive are by weight of modified binder.

The selection of the production and compaction temperatures of the control mixture AR was based on previous studies that considered that the manufacturing temperature of these mixtures usually oscillates between $175^{\circ} \mathrm{C}$ and $180{ }^{\circ} \mathrm{C}(8)$. The AR-WMA mixtures were evaluated and compared in order to assess the effect of the additives when working temperatures are decreased specifically; $-10^{\circ} \mathrm{C},-20^{\circ} \mathrm{C}$ and $-30{ }^{\circ} \mathrm{C}$.

As the rubberized asphalt is still under study and due to the lack of indications in the EN code regulations for AR mixtures, the mix design was carried out according to previous experimental studies. These studies take into account the air void content $(6 \%-8 \%)$, water sensitivity and permanent deformations $(8,25)$.

The main purpose of this type of mixture is to avoid reflective cracking and to extend the durability of the pavement. For this reason, the content of rubber of the modified bitumens is high $(9 \%$ over the weight of aggregates). In order to prevent plastic deformations, they have a strong mineral skeleton and a higher percentage of air voids (7\%) compared to dense asphalt mixtures. This allows the binder's thermal expansion when the temperature is high (summer season) without affecting the resistance to rutting.

\section{METHODS}

\subsection{Determination of bulk density}

The maximum density was determined according to EN 12697-5:2010/AC:2012 (26). Maximum density together with bulk density is required to calculate the void percentage of an asphalt mixture. The bulk density was determined according to EN 12697-6:2012 (27).

The bulk density can be obtained using the mass of the compacted specimens measured in air and in water with the volume of the specimens. In order to obtain the bulk densities, the specimens were compacted at different temperatures with a Marshall hammer according to EN 12697-30:2013 (28), 100 blows, 50 blows on each side. After that, the void percentage of each asphalt mixture was obtained according to EN 12697-8:2003 (29). 
Volumetric characteristics and compactability of asphalt rubber mixtures with organic warm mix asphalt additives $\bullet 5$

TABLE 5. Different methodologies for studying the attainable reduction on production/compaction temperatures of AR-WMA mixtures

\begin{tabular}{lcclc}
\hline $\begin{array}{l}\text { Criteria to determine } \mathbf{T}^{\mathbf{a}} \\
\text { reduction }\end{array}$ & Number of blows & Standard & \multicolumn{1}{c}{ Type of density } & $\begin{array}{c}\text { Number of } \\
\text { samples }\end{array}$ \\
\hline Bulk density/air void content & 100 & EN 12697-6:2012 & $\begin{array}{l}\text { Bulk density } \\
\text { (determined through the saturated } \\
\text { surface dry at the end of compaction) }\end{array}$ & 8 \\
Compactability curves & $\begin{array}{l}200 \\
(100 / \text { side) }\end{array}$ & EN 12697-10:2003 & $\begin{array}{l}\text { Geometric density (depends on the } \\
\text { thickness of the specimen during } \\
\text { compaction) }\end{array}$ & 3 \\
\hline
\end{tabular}

\subsection{Compactability}

This test was carried out according to EN 12697-10:2003 (30) and the specimens were prepared according to EN 12697-30:2013 (28). In order to study the production temperatures of the AR-WMA mixtures, compactability tests were carried out at different temperatures using the Marshall impact compactor.

The specimens were prepared at the selected temperatures and compacted using the Marshall impact compactor with up to 200 blows, 100 blows on each side. During the compaction operation, the change in the specimen thickness was monitored and recorded. Then, the average was calculated to account for some common variability. The compactability was calculated according to the procedure described in EN 12697-10:2003.

Table 5 summarises the methodologies used in this study and to exhibit the differences between them.

\section{RESULTS}

\subsection{Volumetric characteristics}

The volumetric characteristics of the specimens were measured to validate the lower production temperatures of the AR-WMA mixtures. The maximum density depends on the aggregate composition and the content of bitumen of the asphalt mixture but it does not depend on the addition of additives in the blends or on the production temperature. For this reason, all the specimens studied had the same maximum density, which is $2.374 \mathrm{gr} / \mathrm{cm}^{3}$. The production/compaction temperatures, as well as the results obtained for the bulk densities and the air voids content for the AR-WMA mixture, are shown in Table 6.

Comparing the AR-WMA mixtures to the control mixture AR, it can be observed that when the temperature or production/compaction was reduced by $10{ }^{\circ} \mathrm{C}$, the use of the additives reduced the air void content and their respective bulk densities were higher. It can also be noted that the air void content of the AR-WMA mixtures increased as the production/compaction temperature decreased.
TABLE 6. Air voids content

\begin{tabular}{lcccc}
\hline Mixture & $\begin{array}{c}\text { Production } \\
\mathbf{T}^{\mathbf{a}}\left({ }^{\circ} \mathbf{C}\right)\end{array}$ & $\begin{array}{c}\text { Compaction } \\
\mathbf{T}^{\mathbf{a}}\left({ }^{\circ} \mathbf{C}\right)\end{array}$ & $\begin{array}{c}\text { Bulk density } \\
(\mathbf{g r} / \mathbf{c m} 3)\end{array}$ & $\begin{array}{c}\text { Voids } \\
(\%)\end{array}$ \\
\hline AR & 180 & 170 & 2.207 & 7.00 \\
AR+A1 & 170 & 160 & 2.208 & 6.95 \\
& 160 & 150 & 2.198 & 7.37 \\
& 150 & 140 & 2.191 & 7.67 \\
AR+A2 & 170 & 160 & 2.209 & 6.91 \\
& 160 & 150 & 2.198 & 7.37 \\
& 150 & 140 & 2.189 & 7.77 \\
AR+A3 & 170 & 160 & 2.207 & 7.00 \\
& 160 & 150 & 2.199 & 7.33 \\
& 150 & 140 & 2.194 & 7.54 \\
AR+A4 & 170 & 160 & 2.209 & 6.91 \\
& 160 & 150 & 2.201 & 7.25 \\
& 150 & 140 & 2.196 & 7.46 \\
\hline
\end{tabular}

The production temperatures of the AR-WMA mixtures can be calculated based on their volumetric characteristics. The correct compaction temperature can be determined by comparing the bulk density of the AR-WMA mixtures and their control mixture AR. By taking the bulk density of the control mixture after compaction as a reference and comparing it with the density of the AR-WMA mixtures at various temperatures, the temperature at which both densities are identical can be determined. Therefore the correct compaction temperature can be defined to achieve similar densities. In Figure 2, the bulk densities of the different AR-WMA mixtures studied and the control mixture are plotted together.

The attainable reduction of production temperatures was calculated on the basis of the temperature at which the AR-WMA mixtures reach the same density as the control mixture (AR). This was calculated by interpolation (an example made for additive A3 can be seen in Figure 2). Accurate results for each additive are shown in Table 7 . The additive that attained the highest reduction was A4, and A3 was the additive that reached the lowest reduction. It can be noted that the additives attained a similar reduction of the production/compaction temperatures, that being between 10 to $13{ }^{\circ} \mathrm{C}$. 


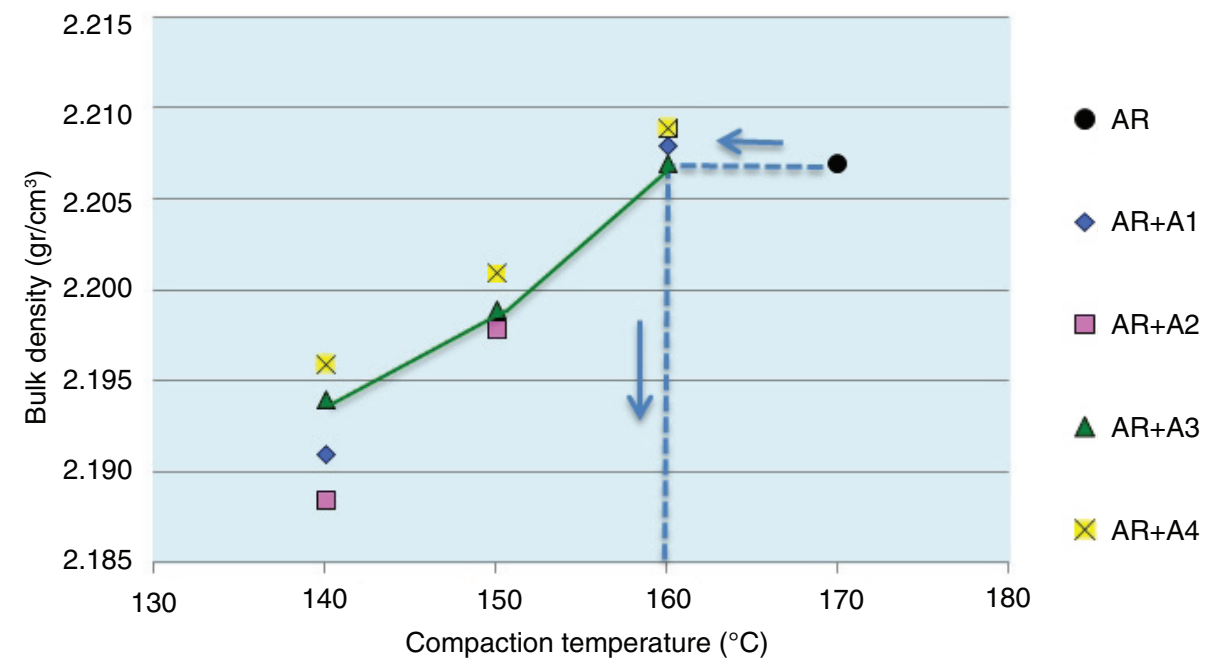

FIGURE 2. Bulk densities of AR-WMA mixtures and the control mixture.

TABLE 7. Reduction in production/compaction temperature

\begin{tabular}{lc}
\hline Mixture & Reduction in production/compaction $\mathbf{T}^{\mathbf{a}}\left({ }^{\circ} \mathbf{C}\right)$ \\
\hline $\mathrm{AR}+\mathrm{A} 1$ & 11.11 \\
$\mathrm{AR}+\mathrm{A} 2$ & 11.92 \\
$\mathrm{AR}+\mathrm{A} 3$ & 10.14 \\
$\mathrm{AR}+\mathrm{A} 4$ & 12.64 \\
\hline
\end{tabular}

In the literature reviewed $(13,31)$, it was observed that a range of compaction temperatures to satisfy the target air void content could be determined. In this particular study, the target air void content was $7 \pm 1 \%$. As can be seen in Table 6 , when the production/compaction temperatures were reduced by $30^{\circ} \mathrm{C}$, the air void content was increased by a maximum of $0.77 \%$, which is the case for $\mathrm{A} 2$; and none of them reached the maximum target air void of $8 \%$ and, therefore, the production/compaction temperatures of the AR-WMA mixtures could be significantly decreased compared to those of the control mixture with a satisfactory air void content. Hence, it appears that the production/compaction temperatures can be reduced by up to $30{ }^{\circ} \mathrm{C}$ without compromising the target air voids content of the mixture.

\subsection{Compactability}

The compaction temperature that can be used for each AR-WMA corresponds to the lowest temperature which results in a density/air void value content similar to that of the control mixture. The results obtained for the AR-WMA with the additives studied and the control mixtures are presented in Figures 3, 4, 5 and 6 where a magnification of the curves was included so they can be better observed.

It should be noted that the compaction was performed at different temperatures; these correspond to a reduction of $10^{\circ} \mathrm{C}, 20^{\circ} \mathrm{C}$ and $30^{\circ} \mathrm{C}$ in comparison to the control mixture which was compacted at $170{ }^{\circ} \mathrm{C}$. It was also decided to plot the curves up to 160 blows (instead of 200) in order to carry out a more thorough observation. Comparing the compaction curves of the different mixtures, it can be seen that the change of the production/compaction temperatures had a significant effect on the compactability as the densities of the mixtures decreased when the temperatures were reduced.

For the AR-WMA mixtures with $\mathrm{A} 1$ and A3 (Figures 3 and 5), it appears that the production/ compaction temperatures could be reduced by $20^{\circ} \mathrm{C}$ as the control mixture curve almost overlapped the mixture curve produced at $150{ }^{\circ} \mathrm{C}$. For the AR-WMA mixture with A2 (Figure 4), it appears that the reduction is about $10^{\circ} \mathrm{C}$ and regarding the AR-WMA mixture with A4 (Figure 6), the temperature could be decreased by $25^{\circ} \mathrm{C}$ as the control mixture curve lay between the mixtures produced at $140{ }^{\circ} \mathrm{C}$ and $150^{\circ} \mathrm{C}$.

It must be pointed out that the densities obtained with the bulk density determination are different to the results obtained with the compactability test. The value of the bulk density is determined on the saturated surface dry (SSD) basis at the end of the compaction process while the density of the compactability test is calculated with the change of the geometric volume of the specimen; therefore, the density depends on the change of the thickness of the specimen. Nevertheless, in both cases, the addition of the waxes allowed a significant reduction in the production/compaction temperatures.

Table 8 summarises the final results of the attainable reduction in production/compaction temperatures depending on the different criteria. From these results, it appears that additive A4 is the one most able to reduce production/compaction temperatures of the AR-WMA mixtures studied. 


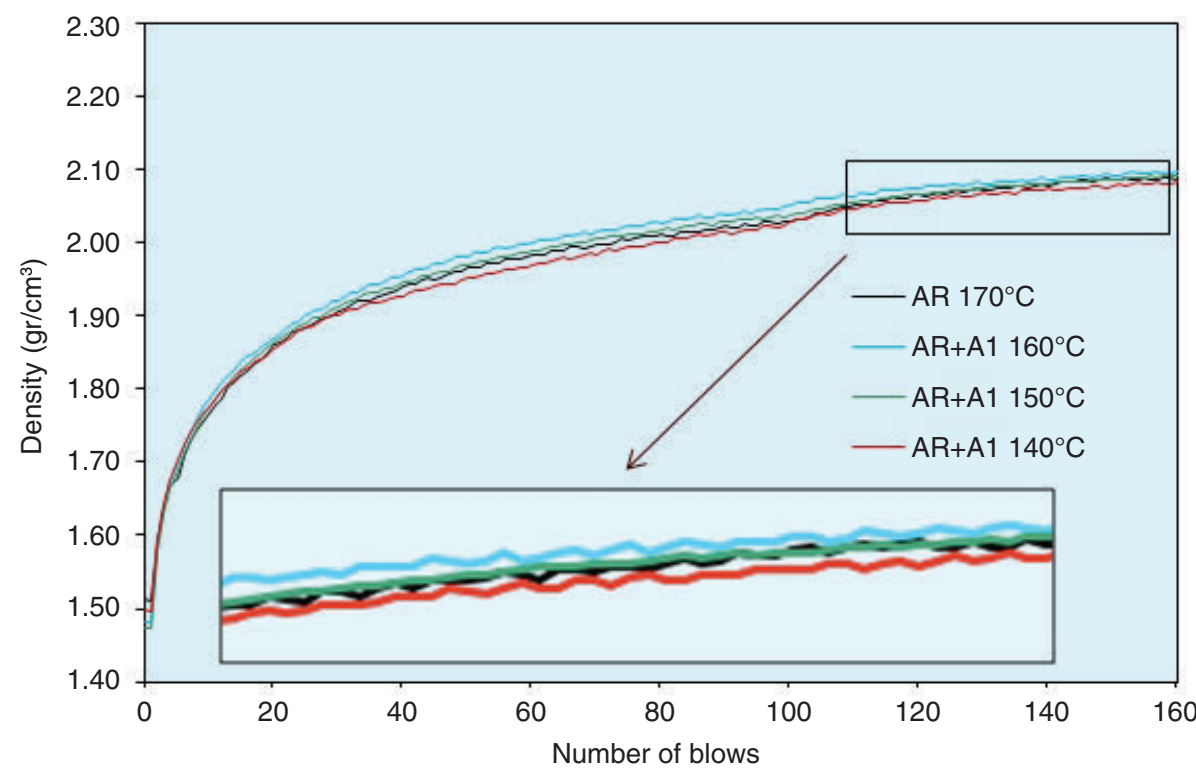

FIgURE 3. Compaction curves of the control mixture and the AR-WMA mixtures with A1.

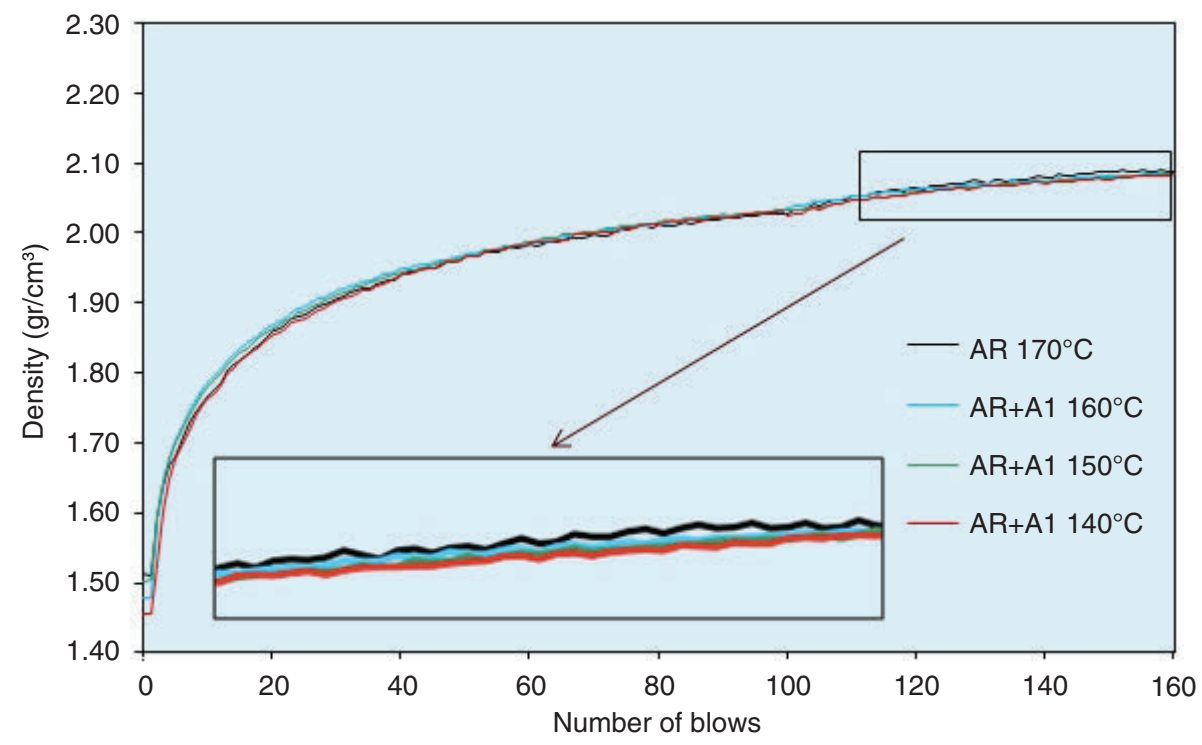

FIGURE 4. Compaction curves of the control mixture and the AR-WMA mixtures with A2.

\section{DISCUSSION}

The results in Table 8 show that lowering production/compaction temperatures of the mixtures under study varied greatly depending on the criterion used for determination. It is, therefore, necessary to identify the most appropriate criterion.

In the bulk density process determined by SSD, the air voids in the peripheral area of the specimen are subtracted in order to calculate their volume. However, the volume considered in the compaction curves is a geometric cylinder, which includes the air voids in the holes of the peripheral area of the specimen.
According to the EN 12697-6 standard regarding bulk density, appendix A determines that the geometric method is appropriate only in the case of mixtures with an air void content above $15 \%$. In this particular case, the air voids in the peripheral area of the specimen are representative of the voids that are also present in the interior of the bituminous mixture. In the case of denser mixtures, the SSD procedure is recommended because the air voids in the peripheral area of the specimen are due to the manufacturing procedure rather than the nature or type of bituminous mixture and therefore need to be subtracted when calculating the volume. 


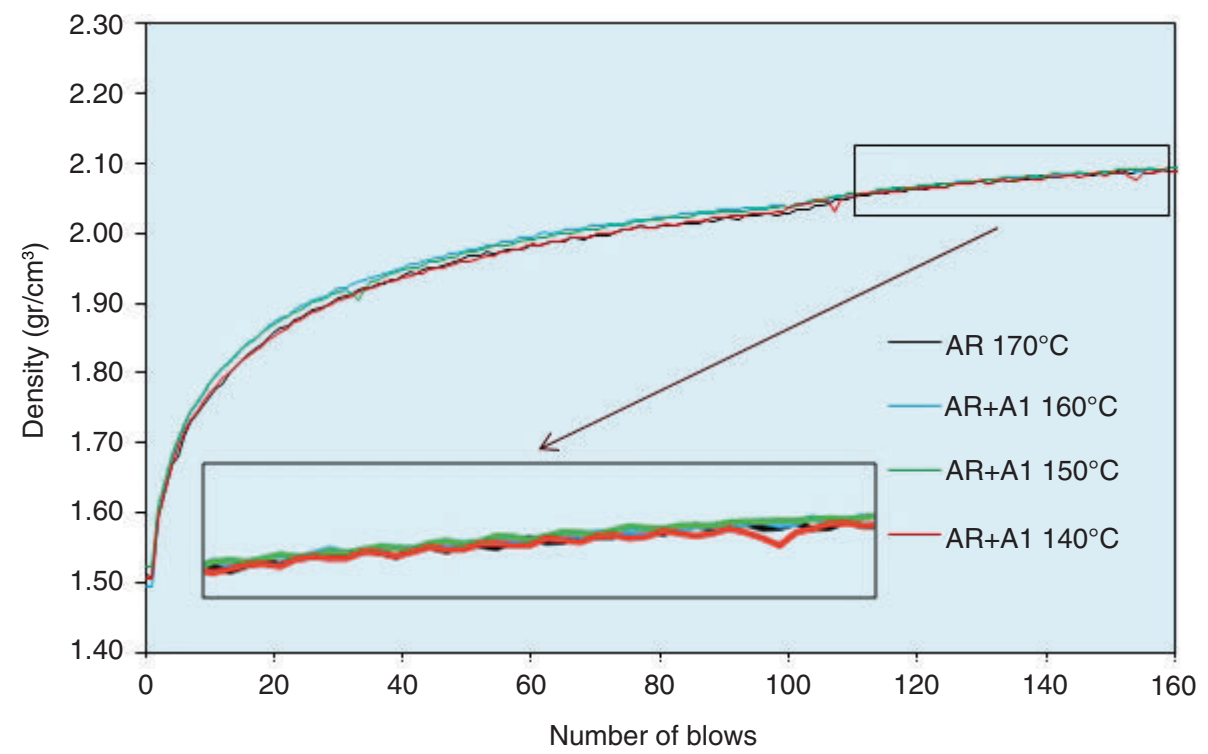

FIGURE 5. Compaction curves of the control mixture and the AR-WMA mixtures with A3.

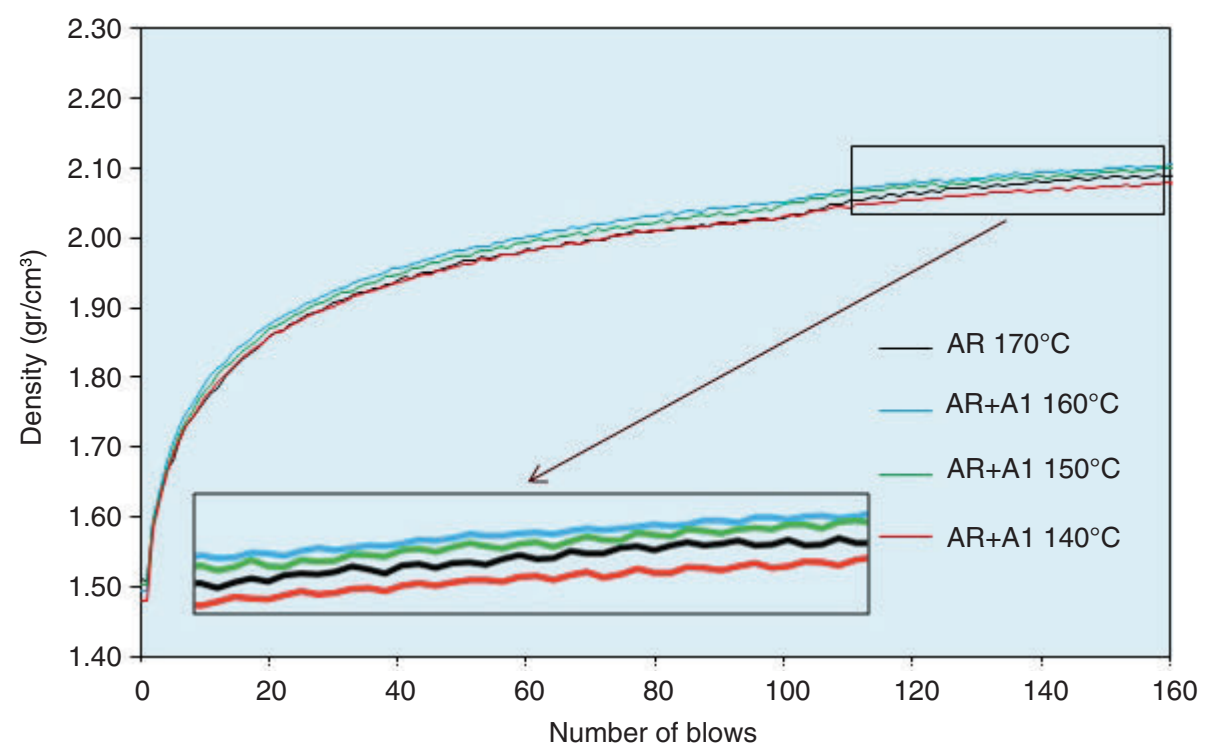

FIgURE 6. Compaction curves of the control mixture and the AR-WMA mixtures with A4.

TABLE 8. Reduction in production/compaction temperatures depending on the criteria used

\begin{tabular}{lcccc}
\hline $\begin{array}{l}\text { Criteria to determine the reduction } \\
\text { in production/compaction } \mathbf{T}^{\mathbf{a}}\left({ }^{\circ} \mathbf{C}\right)\end{array}$ & $\mathbf{Z A R}+\mathbf{A 1}$ & $\mathbf{A R + A 2}$ & $\mathbf{A R + A 3}$ & $\mathbf{A R + \mathbf { A 4 }}$ \\
\hline Bulk density/air void content & $\sim 11^{\circ} \mathrm{C}$ & $\sim 12^{\circ} \mathrm{C}$ & $\sim 10^{\circ} \mathrm{C}$ & $\sim 13^{\circ} \mathrm{C}$ \\
Air void content $\pm 1 \%$ & $>30^{\circ} \mathrm{C}$ & $>30^{\circ} \mathrm{C}$ & $>30^{\circ} \mathrm{C}$ & $>30^{\circ} \mathrm{C}$ \\
Compactability curves & $\sim 20^{\circ} \mathrm{C}$ & $\sim 10^{\circ} \mathrm{C}$ & $\sim 20^{\circ} \mathrm{C}$ & $\sim 25^{\circ} \mathrm{C}$ \\
\hline
\end{tabular}

As the mixture under study has an air void content of approximately $7 \%$, it seems appropriate to consider studies that base their density calculations on the SSD process. In consequence, it would be wiser to establish the temperature reduction based on the criterion supported by bulk density SSD process.

Another point that requires analysis is the criterion of the exact air void content of the control 
mixture or the acceptance of a certain air void range in the mixture. In this case, it was $\pm 1 \%(\mathrm{v} / \mathrm{v})$ compared to the voids in the control mix. As mentioned before, the air void content affects the behaviour of the asphalt mix. Aliha et al. (11) verified that the resistance to fracture at lower temperatures may be reduced by $20 \%$ when the air void content increases from $3 \%$ to $7 \%$. Another study by $\mathrm{Ma}$ et al. (12) reported that the creep behaviour of a bituminous mix at $60{ }^{\circ} \mathrm{C}$ deteriorated exponentially when the air void content increased from $4 \%$ to $8 \%$.

Nevertheless, in both studies, the deterioration of the properties/qualities when the void content increased by $1 \%$ was fairly insignificant. Based on this fact, it seems acceptable to consider the criterion that permits up to $\pm 1 \%$ air void content in order to choose the production/compaction temperature as carried out by other researchers (13-15).

Admitting that the bulk density criterion by SSD process is the most suitable for the type of mixture studied, and the fact that it is possible to equalize bituminous mixtures with the $\pm 1 \%$ criterion, the results obtained in this study reveal that the four additives used may be produced and compacted at $150{ }^{\circ} \mathrm{C}$ and $140{ }^{\circ} \mathrm{C}$ respectively; that is to say $30^{\circ} \mathrm{C}$ lower than the control mix.

The reduction range of $20-30{ }^{\circ} \mathrm{C}$ concerning waxes was reported by Rubio et al. (10) although, in this case, it was mainly for bituminous mixtures without rubber. Akisety (13) accomplished the same temperature reduction for mixtures with a $10 \%$ CRM binder, and Oliveira et al. (15) also reached this temperature reduction using a bituminous mixture with $21 \%$ CRM binder using a surfactant instead of wax.

In any event, the $30^{\circ} \mathrm{C}$ reduction based solely on volumetric characteristics should be confirmed after studying the mechanical properties of the bituminous mixtures. It should be noted that the changes that take place in the mechanical properties depend not only on the lower production temperature and the slightly higher air void content but also on of the effect the waxes have on adherence of aggregate binders and the consistency of the bituminous mixture at different service temperatures. Therefore, a second phase of the study will address the complete mechanical characterization of mixtures produced and compacted at $30{ }^{\circ} \mathrm{C}$ below the control mix.

\section{CONCLUSIONS}

The aim of this study was to determine the attainable reduction of production/compaction temperatures of asphalt rubber (AR) mixtures with Warm Mix Asphalt (WMA) additives. The control mixture was an AR mixture containing 9\% of modified binder $(80 \%$ bitumen, $20 \%$ of crumb rubber modifier (CRM)) referring to the total weight of the dry aggregates. The other twelve mixtures were
AR-WMA mixtures, with also $9 \%$ of binder, which contained $20 \%$ of CRM and $4 \%$ of the additive by the weight of modified binder. The additives used were: a Fischer-Tropsch (F-T) wax (A1), a Montan wax (A2), a refined Montan wax (A3) and a synthetic fatty acid amide (A4).

Two procedures were used to determine the possible temperature reduction that these additives could enable: (a) the study of the bulk density using the saturated surface dry (SSD) method, which does not account for the air void content in the peripheral area of the specimen, and (b) the compactability method that considers the specimen to be a perfect cylinder and that the air voids form part of the specimen volume. As for the bulk density method, measurement was carried out after compaction (50 blows/side). The compactability method reports the specimen's geometric density change during compaction (100 blows/side).

In the bulk density study there are two possibilities: require the same air void content for the AR-WMA mixtures as the control mixture AR, or accept a $\pm 1 \%$ air void of the AR-WMA mixture compared to the control mixture. With the strict criterion regarding air voids, the results reveal that in the case of the additives A1, A2, A3 and A4, the temperature reduction was acceptable at $11,12,10$ and $13{ }^{\circ} \mathrm{C}$ respectively. However, if a $\pm 1 \%$ air void margin is allowed with regard to the control mix, reductions of up to $30{ }^{\circ} \mathrm{C}$ of production/compaction temperature may be obtained for the four additives under study. In contrast, if the densification curve criterion is allowed during compaction, the temperature reduction with additives A1, A2, A3 and $\mathrm{A} 4$ will be $20,10,20$ and $25^{\circ} \mathrm{C}$ respectively.

Given that the type of mixture studied comprised an approximate $7 \%$ air void, procedures that do not take into consideration the air voids in the peripheral area as part of the specimen volume are more appropriate. In this sense, of all the preceding results, the results obtained based on bulk density would appear to be the most appropriate. With regard to the option of equating the bituminous mixtures with a $\pm 1 \%$ air void content difference, the references consulted indicated that the behaviour of the mixture varies very little, with very slight air void content oscillations. In the light of both considerations, it may be concluded that the four additives can be used with temperatures up to $30^{\circ} \mathrm{C}$ lower than the control mixture. This result coincides with the results obtained by other researchers regarding mixtures without rubber and certain examples with rubber.

Nonetheless, the results obtained based on the volumetric characteristics, should be contrasted with a laboratory study with regard to the mechanical properties of the mixtures produced with WMA additives. The differences acquired will be related not only to the void content but also with the effect 
the waxes have on the adherence between the aggregates and the binder and also considering the rheological variations that the WMA additives produce on the mixtures.

\section{ACKNOWLEDGEMENTS}

The authors would like to acknowledge the support received from Ministerio de Economía y Competitividad (MINECO), who financed this research Project BIA2013-47987-C3-1-R.

\section{REFERENCES}

1. Ruth, B.E.; Roque, R. (1995) Crumb rubber modifier (CRM) in asphalt pavements. Proceedings of the Transportation Congress, 768-85.

2. Liang, R.Y.; Lee, S. (1996) Short-term and long-term aging behavior of rubber modified asphalt paving mixtures. Transport Res Rec: J Transport Res Board, 1530:11-7. $\mathrm{http}: / / \mathrm{dx}$.doi.org/10.3141/1530-02

3. Huang, B.; Mohammad, L.N.; Graves, P.S.; Abadie, C. (2002) Louisiana experience with crumb rubber-modified hot-mix asphalt pavement. Transport Res Rec: J Transport Res Board, 1789:1-13. http://dx.doi.org/10.3141/1789-01.

4. Shen, J.; Amirkhanian, S.; Lee, S.J. (2005) Effects of rejuvenating agents on recycled aged rubber modified binders. Int $J$ Pavement Eng, 6(4):273-9. http://dx.doi. org/10.1080/10298430500439319.

5. Moreno, F.; Sol, M.; Martín, J.; Pérez, M.; Rubio, M.C. (2013) The effect of crumb rubber modifier on the resistance of asphalt mixes to plastic deformation. Mater Des, 47, 274-280, 5. http://dx.doi.org/10.1016/j.matdes.2012.12.022.

6. Paje, S.E.; Luong, J.; Vázquez, V.F.; Bueno, M.; Miró, R. (2013) Road pavement rehabilitation using a binder with a high content of crumb rubber: Influence on noise reduction. Constr. Build. Mater., 47 [10] 789-798, https://doi. org/10.1016/j.conbuildmat.2013.05.008

7. Kaloush, K.E. (2014) Asphalt rubber: Performance tests and pavement design issues. Constr. Build. Mater., vol. 67, Part B, 258-264, 9/30. http://dx.doi.org/10.1016/j.conbuildmat.2014.03.020

8. CEDEX. (2007) Manual de empleo de caucho de NFU en mezclas bituminosas. Ministerio de Fomento, Ministerio de Medio Ambiente.

9. Hurley, G.; Prowel, B. (2005) Evaluation of Sasobit ${ }^{\circledR}$ for use in warm mix asphalt. NCAT Report.

10. Rubio, M.C.; Martínez, G.; Baena, L.; Moreno, F. (2012) Warm mix asphalt: an overview. J. Clean. Prod., 24, 76-84, http://dx.doi.org/10.1016/j.jclepro.2011.11.053.

11. Aliha, M.R.M.; Fazaeli, H.; Aghajani, S.; Moghadas Nejad, F. (2015) Effect of temperature and air void on mixed mode fracture toughness of modified asphalt mixtures. Constr. Build. Mater., 95 [1], 545-555, http://dx.doi.org/10.1016/j. conbuildmat.2015.07.165.

12. Ma, T.; Zhang, D.; Zhang, Y.; Zhao, Y.; Huang, X. (2016) Effect of air voids on the high-temperature creep behavior of asphalt mixture based on three-dimensional discrete element modeling. Mater Des, vol. 89, [5] 304-313, http:// dx.doi.org/10.1016/j.matdes.2015.10.005

13. Akisetty, C.K.; Lee, S.; Amirkhanian, S.N. (2009) Effects of compaction temperature on volumetric properties of rubberized mixes containing warm-mix additives. $J$ Mater. Civ. Eng., 21(8), 409-415. http://dx.doi.org/10.1061/ (ASCE)0899-1561(2009)21:8(409).
14. Silva, H.M.R.D.; Oliveira, J.R.M.; Peralta, J.; Zoorob, S.E. (2010) Optimization of warm mix asphalts using different blends of binders and synthetic paraffin wax contents. Constr. Build. Mater., 24 [9] 1621-1631, http://dx.doi.org/ 10.1016/j.conbuildmat.2010.02.030.

15. Oliveira, J.R.M.; Silva, H.M.R.D.; Abreu, L.P.F.; Fernandes, S.R.M. (2013) Use of a warm mix asphalt additive to reduce the production temperatures and to improve the performance of asphalt rubber mixtures. J. Clean. Prod., 41, 15-22, http://dx.doi.org/10.1016/j.jclepro.2012.09.047.

16. Rodríguez-Alloza, A.M.; Gallego, J.; Pérez, I.; Bonati, A.; Giuliani, F. (2014) High and low temperature properties of crumb rubber modified binders containing warm mix asphalt additives. Constr. Build. Mater., 53(0), 460-466. http://dx.doi. org/10.1016/j.conbuildmat.2013.12.026.

17. CEN. (2003). EN 1426. Bitumen and bituminous binders Determination of needle penetration.

18. CEN. (2007). EN 1427:2007. Bitumen and bituminous binders - Determination of the softening point - Ring and Ball method.

19. CEDEX. (1999). Normas NLT. I, Ensayos de carreteras. NLT 373/94, fraccionamiento de los betunes asfálticos.

20. Hossain, M.; Swartz, S.; Hoque, E. (1999) Fracture and tensile characteristics of asphalt-rubber concrete. $J$. Mater. Civ. Eng. 11(4), 287-294. http://dx.doi.org/10.1061/ (ASCE)0899-1561(1999)11:4(287).

21. Sousa, J.; Pais, J.; Saim, R.; Way, G.; Stubstad, R. (2002) Mechanistic-empirical overlay design method for reflective cracking. Transport Res Rec: J Transport Res Board, 1809(-1), 209-217. http://dx.doi.org/10.3141/1809-23.

22. Wang, H.; You, Z. (2011) Intermediate temperature fatigue and low temperature cracking properties of rubber asphalt binder. 11th International Conference of Chinese Transportation Professionals: Towards Sustainable Transportation Systems, ICCTP 2011, August 14, 2011 August 17, 4121-4131. http://dx.doi.org/10.1061/41186 (421) 411 .

23. Anderson, D.; Marasteanu, M.; Mahoney, J.; Stephens, J. (2000) Factors affecting the variability in the SHRP binders tests. proceedings of the 79th annual meeting of the Transportation Research Board.

24. Soenen, H.; Visscher, J.;De Vanelstraete, A.; Redelius, P. (2006) Influence of thermal history on rheological properties of various bitumen. Rheol Acta, 45(5), 729-739. http:// dx.doi.org/10.1007/s00397-005-0032-8.

25. Gallego, J.; Castro, M.; Prieto, J.N.; Vasallo, J.M. (2007) Thermal sensitivity and fatigue ife of gap-graded asphalt mixes incorporating crumb rubber from tire waste, Transport Res Rec: J Transport Res Board, vol. 1998, 132-139. http://dx.doi.org/10.3141/1998-16.

26. CEN. (2012). EN 12697-5:2010/AC:2012. Bituminous mixtures - test methods for hot mix asphalt - Part 5: Determination of the maximum density.

27. CEN. (2012). EN 12697-6:2012. bituminous mixtures - test methods for hot mix asphalt - part 6: Determination of bulk density of bituminous specimens.

28. CEN. (2013) EN 12697-30:2013. Bituminous mixtures Test methods for hot mix asphalt - Part 30: Specimen preparation by impact compactor.

29. CEN. (2003) EN 12697-8:200. Bituminous mixtures - Test methods for hot mix asphalt - Part 8: Determination of void characteristics of bituminous specimens.

30. CEN. (2003) EN 12697-10:2003. Bituminous mixtures. Test methods for hot mix asphalt. Part 10: Compactability.

31. Lee, S.; Amirkhanian, S.N.; Kwon, S. (2008) The effects of compaction temperature on CRM mixtures made with the SGC and the marshall compactor. Constr. Build. Mater., 22(6), 1122-1128. http://dx.doi.org/10.1016/j. conbuildmat.2007.03.003. 